\title{
PENERAPAN MODEL PEMBELAJARAN KOOPERATIF TIPE STAD DAPAT MENINGKATKAN KEAKTIFAN DAN KEMAMPUAN MENGHITUNG PECAHAN
}

\author{
Sriyanto \\ SDN Pranan 02 \\ sriyanto@bptikpjateng.org
}

\begin{abstract}
In the Unit Level curriculum Mathematics education needs to be given to all students starting from elementary school to equip students with the ability to think logically, analytically, systematically, critically, and creatively, and the ability to cooperate. The purpose of this study is to increase the activity and student learning outcomes through the Cooperative type STAD learning model. This research is a classroom action research that uses data collection methods with Milles and Hubberman interactive models including data reduction, data presentation, and conclusion drawing. The results of this study indicate an increase in activity in students from $63,21 \%$ in the first cycle to $84,28 \%$ in the second cycle. The development of activity followed by the development of student learning outcomes reached KKM from $30.43 \%$ pre cycle, increased $65.22 \%$ in cycle one and $91.30 \%$ in cycle two. Based on data analysis, it shows that the indicator of success has been achieved in the second cycle, after achieving the indicator of success that is equal to $280 \%$, and the average learning outcomes have been above the specified minimum completeness ratio (70).
\end{abstract}

Keywords: Cooperative, Method of teaching, STAD

Dalam kurikulum Tingkat Satuan Pendidikan mata pelajaran Matematika perlu diberikan kepada semua peserta didik mulai dari sekolah dasar untuk membekali peserta didik dengan kemampuan berpikir logis, analitis, sistematis, kritis, dan kreatif, serta kemampuan bekerjasama. Tujuan penelitian ini adalah meningkatkan keaktifan dan hasil belajar siswa melalui model pembelajaran Kooperatif tipe STAD. Penelitian ini adalah penelitian tindakan kelas yang menggunakan metode pengumpulan data dengan model interaktif Milles dan Hubberman meliputi reduksi data, penyajian data, dan penarikan kesimpulan. Hasil penelitian ini menunjukan kenaikan keaktifan pada siswa dari $63,21 \%$ pada siklus satu menjadi $84,28 \%$ pada siklus dua. Perkembangan keaktifan diikuti dengan perkembangan hasil belajar siswa mencapai KKM dari $30,43 \%$ pra siklus, meningkat $65,22 \%$ pada siklus satu dan $91,30 \%$ pada siklus dua. Berdasarkan analisis data, menunjukkan bahwa indikator keberhasilan telah tercapai pada siklus kedua, setelah mencapai indikator keberhasilan yaitu sebesar $\geq 80 \%$, dan rata-rata hasil belajar sudah di atas riteria kelengkapan minimum yang ditentukan (70).

Kata Kunci : Kooperatif, STAD, Metode mengajar

\section{PENDAHULUAN}

Pendidikan adalah salah satu cara untuk meningkatkan sumber daya manusia. Dengan pendidikan orang akan mempunyai bekal dalam memecahkan masalah yang di hadapi dalam kehidupannya. Pengertian pendidikan sesuai dengan Undang-Undang Republik Indonesia Nomor 2 Tahun 1989 Tentang Sistem Pendidikan Nasional disebutkan bahwa pendidikan adalah usaha untuk menyiapkan peserta didik melalui kegiatan bimbingan, pengajaran, dan latihan bagi peranannya di masa yang akan datang. Dengan memperhatikan pengertian pendidikan seperti yang disebutkan diatas, maka dapat dinyatakan bahwa peran pendidikan adalah sebagai landasan untuk membentuk, mempersiapkan, membina, dan mengembangkan kemampuan sumber daya manusia yang sangat menentukan dalam keberhasilan pembangunan di masa yang akan datang.
Berdasarkan Undang-Undang Nomor 20 tahun 2003 tentang Sistem Pendidikan Nasional Pasal 36 Ayat (2) ditegaskan bahwa kurikulum pada semua jenjang dan jenis pendidikan dikembangkan dengan prinsip diversifikasi sesuai dengan satuan pendidikan, potensi daerah, dan peserta didik. Serta Pasal 3 Undang-Undang Sistem Pendikan Nasional menyebutkan "Pendidikan nasional berfungsi mengembangkan dan membentuk watak serta peradaban bangsa yang bermartabat dalam rangka mencerdaskan kehidupan bangsa, bertujuan untuk berkembangnya potensi peserta didik agar menjadi manusia yang beriman dan bertaqwa kepada Tuhan Yang Maha Esa, berakhlak mulia, sehat, berilmu, cakap, kreatif, mandiri, dan menjadi warga negara yang demokratis serta bertanggung jawab". Menurut Kurikulum Tingkat Satuan Pendidikan mata pelajaran Matematika perlu diberikan kepada semua 
peserta didik mulai dari sekolah dasar untuk membekali peserta didik dengan kemampuan berpikir logis, analitis, sistematis, kritis, dan kreatif, serta kemampuan bekerjasama (Depdiknas, 2006).

Berdasarkan hasil nilai ulangan yang telah dilakukan di kelas V SD Negeri Pranan 02 Tahun Pelajaran 2018/ 2019, dari hasil ulangan materi menghitung pecahan, hasil belajar siswa masih rendah. Dari 23 Siswa yang nilainya mencapai Kriteria Ketuntasan Minimal (KKM) 7 siswa 30,43\% dan untuk siswa selebihnya diperlukan remedial. Dari hasil ulangan ini menunjukkan bahwa 16 siswa $57,14 \%$ siswa masih belum memenuhi KKM dalam menghitung pecahan. Maka dari itu, pembelajaran matematika kopetensi menghitung pecahan perlu diperbaiki.

Salah satu alternatif yang dapat ditempuh untuk meningkatkan kemampuan belajar siswa dalam mata pelajaran matematika adalah melalui kreativitas yang dimiliki guru dalam memilih model mengajar. Model belajar yang tepat akan menarik minat dan secara tidak sadar menuntut siswa untuk belajar, maka tujuan yang diharapkan akan tercapai.

Salah satu cara yang dapat diterapkan adalah dibentukya kelompok-kelompok kecil dalam pembelajaran kooperatif maka interaksi antar anggota kelompok menjadi maksimal dan efektif, sehingga perbedaan kecepatan dan kemampuan tiap-tiap individu dapat diperkecil. Dengan demikian diharapkan bagi siswa yang mempunyai kecepatan dan kemampuan yang kurang dapat tertolong oleh temannya dalam satu kelompok yang mempunyai kemampuan lebih baik. Siswa yang mempunyai kemampuan sedang akan dapat segera menyesuaikan dalam proses pemahaman materi.

Materi pecahan merupakan salah satu materi dalam mata pelajaran matematika. Materi ini dianggap cukup sulit oleh sebagian besar siswa karena di dalam pengerjaannya dibutuhkan suatu pemahaman. Oleh sebab itu, diperlukan cara yang mudah untuk menyampaikan bahan pelajaran. Penerapan model pembelajaran kooperatif tipe Student Teams-Achievement Divisions (STAD) diharapkan bisa memotivasi siswa untuk lebih siap belajar matematika tanpa ada rasa takut untuk mempelajarinya. Siswa diharapkan dapat melatih dan meningkatkan keterampilan berkomunikasi dan berinteraksi dengan siswa lain dalam suasana yang menarik.

Model kooperatif tipe Student TeamsAchievement Divisions (STAD) dapat membentuk aktivitas sosial siswa di kelas. Maka dari itu, siswa diharapkan akan lebih mudah dalam memahami pelajaran sehingga kemampuan dalam menghitung pecahan akan meningkat. Berdasarkan uraian di atas, maka penulis mengadakan penelitian dengan tujuan Meningkatkan Kemampuan Menghitung Pecahan Melalui Penerapan Model Pembelajaran Kooperatif Tipe Student TeamsAchievement Divisions (STAD) Pada Siswa Kelas V SD Negeri Pranan 02 Tahun Ajaran 2018/ 2019.

\section{KAJIAN PUSTAKA}

Kemampuan berasal dari kata mampu yang artinya kuasa atau berada. Kata mampu yang mendapat awalan ke- dan akhiran -an, akan menjadi kata kemampuan yang selanjutnya memiliki arti kesanggupan, kecakapan, kekuatan atau kekayaan (Hasan Alwi, 2005:707). Menurut Masykur dan Fathani (2008) kemampuan berhitung adalah penguasaan terhadap ilmu hitung dasar yang merupakan bagian dari matematika yang meliputi penjumlahan, pengurangan, perkalian dan pembagian. Berdasarkan uraian di atas dapat disimpulkan bahwa kemampuan menghitung adalah kesanggupan anak dalam penguasaan ilmu hitung yang meliputi penjumlahan, pengurangan, perkalian dan pembagian terhadap bilangan-bilangan tertentu. Salah satu mata pelajaran di sekolah dasar yang memuat aspek menghitung adalah mata pelajaran matematika.

Menurut Johnson \& johnson (1994) dalam Isjoni (2009: 63) menyebutkan bahwa pembelajaran kooperatif adalah mengerjakan sesuatu bersama- sama dengan saling membantu satu sama lainya sebagai tim untuk mencapai tujan bersama. Pembelajaran kooperatif merupakan pendekatan atau serangkaian strategi yang khusus dirancang untuk member dorongan kepada peserta didik agar bekerja sama selama berlangsungnya proses pembelajaran yang telah dikemukakan Sunal dan hans ( 1993 ) dalam Isjoni ( 2009: 64 
). Menurut Slavin (1987) dalam Kamuran Tarim dan Fikri Akdenis (2008) disebutkan bahwa cooperative learning is a set of instructional method that requires students to work in small, mixed-ability learning groups. Dapat diartikan bahwa pembelajaran kooperatif merupakan seperangkat metode instruksional di mana siswa membutuhkan bekerja dalam kelompok kecil yang menggabungkan kemampuan dalam kelompok belajar Menurut Slavin (2008) dalam Effandi Zakaria and Zanaton Iksan, disebutkan bahwa Cooperative learning is generally understood as learning that takes place in small groups where students share ideas and work collaboratively to complete a given task. There are several models of cooperative learning that vary considerably from each other. Pembelajaran kooperatif secara umum dipahami sebagai pembelajaran yang terjadi dalam kelompok kecil dimana siswa berbagi ide dan bekerja sama menyelesaikan suatu soal. Ada beberapa model pembelajaran kooperatif yang berbeda satu sama lainnya. Dalam Agus Suprijono ( 2009: 54 ) menerangkan bawa pembelajaran kooperatif adalah konsep yang lebih luas meliputi semua jenis kerja kelompok termasuk bentuk- bentuk yang lebih dipimpin oleh guru atau diarahkan oleh guru. Dan menurut Sugiyanto (2009:37) Pembelajaran kooperatif (Cooperative learning) adalah pendekatan pembelajaran yang berfokus pada penggunaan kelompok kecil siswa untuk bekerja sama dalam memaksimalkan kondisi belajar untuk mencapai tujuan belajar. Berdasarkan definisi-definisi di atas dapat disimpulkan bahwa pembelajaran kooperatif (cooperative leraning) adalah model pembelajaran yang menggunakan kelompokkelompok kecil dimana siswa dalam satu kelompok saling bekerja sama memecahkan masalah untuk mencapai tujuan pembelajaran.

Pembelajaran kooperatif merupakan pendekatan atau serangkaian strategi yang khusus dirancang untuk member dorongan kepada peserta didik agar bekerja sama selama berlangsungnya proses pembelajaran yang telah dikemukakan Sunal dan hans ( 1993 ) dalam Isjoni ( 2009: 64 ).Menurut Slavin (1987) dalam Kamuran Tarim dan Fikri Akdenis (2008) disebutkan bahwa cooperative learning is a set of instructional method that requires students to work in small, mixedability learning groups. Dapat diartikan bahwa pembelajaran kooperatif merupakan seperangkat metode instruksional di mana siswa membutuhkan bekerja dalam kelompok kecil yang menggabungkan kemampuan dalam kelompok belajar. Berdasarkan definisidefinisi di atas dapat disimpulkan bahwa pembelajaran kooperatif (cooperative leraning) adalah model pembelajaran yang menggunakan kelompok-kelompok kecil dimana siswa dalam satu kelompok saling bekerja sama memecahkan masalah untuk mencapai tujuan pembelajaran.

Student Teams-Achievement Divisions (STAD) merupakan salah satu metode pembelajaraan kooperatif yang paling sederhana, dan merupakan model yang paling baik untuk permulaan bagi para guru yang menggunakan pendekatan kooperatif (Salvin, 2009: 143). Student Teams-Achievement Divisions (STAD) is a cooperative learning method for mixed-ability groupings involving team recognition and group responsibility for individual learning. Dari definisi tersebut dikemukakan bahwa Student TeamsAchievement Divisions (STAD) adalah sebuah pembelajaran kooperatif yang menggabungkan berbagai tingkat kemampuan yang terdapat pengakuan tim dan tanggung jawab kelompok untuk pembelajaran individu

(http://www.ejmste.com/Promoting-

Cooperative-Learning-in-nScience-and-

Mathematics-nEducation-A-Malaysian-

Perspective, 75372,0,2.html, 17/01/2019). Menurut Slavin (2009: 143-146), Student Teams-Achievement Divisions (STAD) merupakan salah satu model pembelajaran kooperatif yang paling sederhana. Pada pembelajaran kooperatif Student TeamsAchievement Divisions (STAD) siswa dikelompokkan dalam tim-tim pembelajaran dengan empat anggota atau lebih campuran ditinjau dari tingkat kinerja, jenis kelamin, status sosial dan sebagainya. Guru mempresentasikan pelajaran, kemudian siswa bekerja di dalam tim-timnya untuk memastikan bahwa seluruh anggota tim telah menuntaskan pelajaran yang telah dipresentasikan oleh guru, akhirnya diadakan kuis-kuis secara individual 
tentang bahan ajar tersebut, tanpa diperkenankan membantu satu sama lainnya.

Pembelajaran kooperatif adalah suatu sistem yang didalamnya terdapat elemenelemen yang saling terkait. Elemen-elemen pembelajaran kooperatif itu adalah saling ketergantungan positif, interaksi tatap muka, akuntabilitas individual, dan keterampilan untuk menjalin hubungan antar pribadi atau keterampilan sosial yang secara sengaja diajarkan (Lie dalam Sugiyanto, 2009: 40- 42). Elemen-elemen dalam pembelajaran kooperatif terdiri dari 1)Saling Ketergantungan Positif; 2) Interaksi Tatap Muka; 3) Akuntabilitas Individual; 4) Keterampilan Menjalin Hubungan antar Pribadi. Student Teams-Achievement Divisions (STAD) terdiri atas lima komponen utama yaitu, presentasi kelas, tim, kuis dan skor kemajuan individul. Berdasarkan definisi di atas dapat disimpulkan bahwa Student Teams-Achievement Divisions (STAD) adalah salah satu jenis pembelajaran kooperatif yang menggabungkan siswa dari berbagai tingkat kemampuan, yang di dalamnya terdapat pengakuan dan tanggung jawab tim untuk pembelajaran individual.

Dari hasil identifikasi Deuthsch(1949) dalam Salvin ( 2009: 34 ) ada tiga struuktur tujuan pembelajaran kooperatif, 1)Meskipun pembelajaran kooperatif meliputi berbagai macam tujuan sosial, tetapi juga bertujuan untuk meningkatkan kinerja siswa dalam tugas-tugas akademik. Beberapa ahli berpendapat bahwa model ini unggul dalam membantu siswa memahami konsep-konsep yang sulit. Model struktur penghargaan kooperatif juga telah dapat meningkatkan penilaian siswa pada belajar akademik dan perubahan norma yang berhubungan dengan hasil belajar; 2)Penerimaan yang luas terhadap orang yang berbeda menurut ras, budaya, kelas sosial, kemampuan, maupun ketidakmampuan. Pembelajaran kooperatif memberikan peluang kepada siswa yang berbeda latarbelakang dan kondisi untuk bekerja saling bergantung satu sama lain atas tugas-tugas bersama, dan melalui penggunaan struktur penghargaan kooperatif, belajar untuk menghargai satu sama lain; 3) Tujuan penting ketiga dari pembelajaran kooperatif adalah mengajarkan kepada siswa keterampilan kerjasama dan kolaborasi. Keterampilan ini penting karena banyak anak muda dan orang dewasa masih kurang dalam keterampilan sosial.

Tujuan utama dalam penerapan model pemebelajaran kooperatif adalah agar peserta didik dapat belajar secara berkelompok bersama teman- temanya dengan cara saling menghargai pendapat dan memberikan kesempatan kepada orang lain untuk mengemukakan gagasanya dengan menyampaikan pendapat mereka secara berkelompok ( Isjoni, 2009: 9 ).

\section{METODE}

Berdasarkan permasalahan yang dihadapi Model PTK yang digunakan adalah model Kemmis dan Mc Taggart. Menurut Kemmis dan Mc Taggart (1988: 11) penelitian tindakan dapat dipandang sebagai suatu siklus spiral dari penyusunan perencanaan, pelaksanaan tindakan, pengamatan, dan refleksi yang selanjutnya mungkin diikuti dengan siklus spiral berikutnya. Siklus dalam penelitian tindakan dilakukan secara berulang dan berkelanjutan (siklus spiral), yaitu proses pembelajaran yang semakin lama semakin meningkat pencapaian hasilnya.

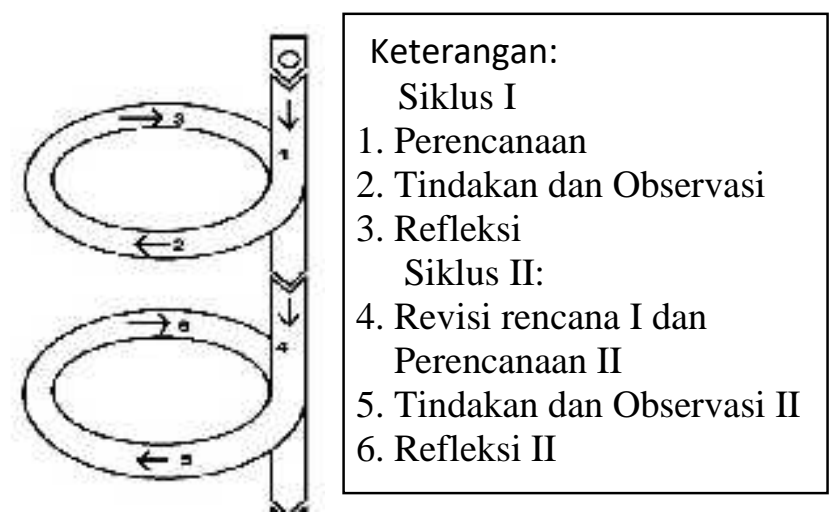

Gambar 1 Model PTK Kemmis \& Taggart (1988: 11)

Adapun langkah- langkah pelaksanaan PTK dilakukan melalui 4 tahap yaitu: perencanaan tindakan yang meliputi kegiatan membuat perangkat pembelajaran, membuat lembar observasi, membuat alat evaluasi, dan melakukan validasi; pelaksanaan yang berisi kegiatan pelaksanakan kegiatan pembelajaran; observasi yang berisi kegiatan pengamatan terhadap pelaksanaan tindakan; dan terakhir refleksi berisi kegiatan diskusi tentang hasil penelitian untuk mengetahui seberapa jauh tindakan telah memberikan pengaruh. 
Subjek dalam penelitian ini adalah guru dan seluruh siswa kelas V SD Negeri Pranan 02 Polokarto sebanyak 23 siswa terdiri dari 6 siswa putra dan 17 siswa putri. Penelitian ini akan dilaksanakan di SD Negeri Pranan 02 Kecamatan Polokarto Kabupaten Sukoharjo pada semester II tahun pelajaran 2018/ 2019.

Teknik pengumpulan data yang digunakan dalam penelitian ini meliputi: observasi dengan menggunakan lembar pengamatan terhadap keaktifan siswa; tes soal pilihan ganda dan essay untuk mengetahui skor hasil belajar. Sedangkan instrumen penelitian yang digunakan adalah: lembar pengamatan keterlaksanaan pembelajaran untuk mengamati keaktifan siswa dalam proses pembelajaran; Lembar Kegiatan Siswa (LKS) sebagai petunjuk siswa dalam melaksanakan kegiatan pembelajaran; lembar tes dalam bentuk pilihan ganda dan essay.

Teknik analisis data untuk mengetahui menegetahui prosentase keaktifan digunakan rumus

$$
\mathrm{P}=\frac{\mathrm{F}}{\mathrm{N}} \times 100 \%
$$

$\mathrm{P}=$ Persentase kekatifan Siswa

$\mathrm{F}=$ Jumlah frekuensi tiap keaktifan yang muncul

$\mathrm{N}=$ Jumlah total frekuensi keaktifan siswa

Untuk menentukan reliabilitas instrumen kekatifan siswa, digunakan rumus percentage of agreement sebagai berikut:

$$
\text { Percentage of Agreement }=\left(1-\frac{[A-B]}{[A+B]}\right) \times 100 \%
$$

Keterangan:

$\mathrm{A}=$ Frekuensi aspek tingkah laku yang teramati oleh pengamat dengan memberikan frekuensi tinggi

$\mathrm{B}=$ Frekuensi aspek tingkah laku yang teramati oleh pengamat dengan memberikan frekuensi rendah

Instrumen dikatakan baik jika mempunyai koefisien reliabilitas $\geq 0,75$ atau $\geq 75 \%$ (Borich, 1994: 385).
Tabel 1 Kriteria Keaktifan Siswa

\begin{tabular}{cl}
\hline $80 \%-100 \%$ & $=$ Sangat Baik \\
\hline $66 \%-79 \%$ & $=$ Baik \\
\hline $56 \%-65 \%$ & $=$ Cukup \\
\hline $40 \%-55 \%$ & $=$ Kurang Baik \\
\hline$<40 \%$ & $=$ Gagal \\
\hline & (Arikunto, 2013: 281)
\end{tabular}

Keaktifan siswa dikatakan efektif apabila siswa mencapai keberhasilan keaktifan dalam penelitian ini yaitu $\geq 80 \%$ kekatifan pembelajaran dilaksanakan oleh siswa atau dalam kategori sangat baik.

Analisis hasil belajar siswa diperoleh dari hasil tes siswa. Catatan (data) hasil tes siswa dianalisis berdasarkan pedoman penskoran untuk setiap jawaban soal yang telah dibuat oleh peneliti. Penilaian hasil tes tertulis setiap peserta didik dhitung dengan rumus:

Nilai $=\underline{\text { Jumlah skor yang diperoleh }} \times 100$

(Arikunto, 2013: 272)

Hasil tes yang diperoleh setelah pelaksanaan tindakan kemudian diolah untuk mengetahui ketuntasan hasil belajar yang dicapai siswa. Untuk menghitung nilai rata-rata kelas digunakan rumus:

$$
M=\frac{\sum x}{N}
$$

(Sudjana, 2012:109)

Keterangan:

$\mathrm{M}=$ rata-rata (mean)

$\Sigma \mathrm{X}=$ jumlah nilai seluruh siswa

$\mathrm{N}=$ jumlah siswa

Setelah dilakukan perhitungan terhadap nilai hasil belajar dan rata-rata hasil belajar matematika satu kelas, langkah selanjutnya adalah mencari presentase ketuntasan klasikal siswa terhadap proses pembelajaran. Untuk analisis ketuntasan belajar klasikal siswa terhadap proses pembelajaran dinyatakan dalam persentase dengan rumus sebagai berikut:

$$
\begin{aligned}
& \mathrm{P}=\frac{\Sigma \mathrm{X}}{\Sigma \mathrm{N}} \times 100 \% \\
& \text { (Kunandar, 2013:137) }
\end{aligned}
$$


Keterangan :

$\mathrm{P}=$ Presentase ketuntasan belajar klasikal

$\Sigma \mathrm{X}=$ Jumlah siswa yang mencapai KKM $(\geq 75)$

$\sum \mathrm{N}=$ Jumlah siswa seluruhnya

Untuk memudahkan dalam mengetahui taraf keberhasilannya, dibuat rentang kriteria penilaian ketuntasan hasil belajar setelah diperlakukan model pembelajaran kooperatif tipe Student Teams-Achievement Divisions (STAD). Kriteria penilaian ketuntasan hasil belajar siswa secara klasikal adalah sebagai berikut

\section{HASIL DAN PEMBAHASAN}

Pelaksanaan tindakan dilakukan sebanyak dua siklus pembelajaran dengan dua kali pertemuan di setiap siklusnya. Kegiatan pembelajaran pada tahap pelaksanaan setiap siklusnya engacu pada RPP yang telah disusun dan divalidasi pada tahap perencanaan. Tahapan dalam PBM terdiri dari lima fase yaitu: Fase-1 menyampaikan tujuan dan memotivasi siswa, Fase-2 menyajikan/ menyampaikan informasi, Fase-3 mengorganisasikan siswa dalam kelompokkelompok belajar, Fase-4 membimbing kelompok bekerja dan belajar, Fase-5 evaluasi, dan Fase-6 memberikan penghargaan.

Data hasil pengamatan keterlaksanaan pembelajaran Siklus I dan Siklus II tentang keaktifan siswa dapat dilihat pada Tabel 3 berikut.

Tabel 3. Data Keaktifan Siswa

\begin{tabular}{clcc}
\hline No. & Kategori Nilai & $\begin{array}{c}\text { Persentase } \\
\text { Siklus I } \\
(\%)\end{array}$ & $\begin{array}{c}\text { Persentase } \\
\text { Siklus II } \\
(\%)\end{array}$ \\
\hline 1 & $\begin{array}{l}\text { Mendengarkan } \\
\text { penjelasan guru/ } \\
\text { teman }\end{array}$ & 78,26 & 86,96 \\
\hline 2 & Membaca materi & 78,26 & 86,96 \\
\hline 3 & $\begin{array}{l}\text { Menulis/mencatat } \\
\text { materi }\end{array}$ & 65,22 & 82,61 \\
\hline 4 & Mengerjakan LKS & 78,26 & 78,26 \\
\hline 5 & $\begin{array}{l}\text { Berdiskusi dengan } \\
\text { guru }\end{array}$ & 43,48 & 78,26 \\
\hline 6 & $\begin{array}{l}\text { Mengajukan } \\
\text { pertanyaan pada } \\
\text { teman atau guru }\end{array}$ & 52,17 & 73,91 \\
\hline 7 & $\begin{array}{l}\text { Menjadi } \\
\text { pembicara } \\
\text { kelompok }\end{array}$ & 47,83 & 82,61 \\
\hline
\end{tabular}

\begin{tabular}{clcc}
\hline No. & Kategori Nilai & $\begin{array}{c}\text { Persentase } \\
\text { Siklus I } \\
(\%)\end{array}$ & $\begin{array}{c}\text { Persentase } \\
\text { Siklus II } \\
(\%)\end{array}$ \\
\hline 8 & $\begin{array}{l}\text { Menghargai } \\
\text { pendapat orang } \\
\text { lain }\end{array}$ & 60,87 & 91,30 \\
\hline 9 & $\begin{array}{l}\text { Mengambil giliran } \\
\text { dan berbagi tugas }\end{array}$ & 52,17 & 86,96 \\
\hline 10 & $\begin{array}{l}\text { Memberi } \\
\text { kesempatan orang } \\
\text { lain berbicara }\end{array}$ & 69,57 & 86,96 \\
\hline 11 & $\begin{array}{l}\text { Mendengarkan } \\
\text { dengan aktif }\end{array}$ & 69,57 & 86,96 \\
\hline 12 & $\begin{array}{l}\text { Kerja sama dalam } \\
\text { kepompok }\end{array}$ & 73,91 & 86,96 \\
\hline 13 & $\begin{array}{l}\text { Kemampuan } \\
\text { menyampaikan } \\
\text { informasi }\end{array}$ & 52,17 & 86,96 \\
\hline
\end{tabular}

Tabel 3 menunjukkan persentase modus nilai ketercapaian keaktifan siswa pada Siklus I berkategori cukup mencapai $63,21 \%$, sedangkan persentase modus nilai ketercapaian keaktifan siswa pada Siklus II meningkat menjadi kategori sangat baik dengan persentase mencapai 84,28\%.

Data tersebut menunjukkan adanya peningkatan ketercapaian keaktifan siswa berdasarkan kegiatan belajar mengajar yang dilakukan guru dan siswa dari Siklus I ke Siklus II. Pembelajaran Matematika di SD Negeri Pranan 02 yang sebelumnya guru hanya menggunakan metode ceramah. Siswa kurang aktif dalam proses pembelajaran karena metode yang digunakan secra konvensional hanya ceramah, jarang terlihat siswa melakukan diskusi, melakukan percobaan, merancang dan menyajikan hasil karya, dan bertanya maupun menjawab pertanyaan yang diberikan guru.

Dengan penerapan model pembelajaran kooperatif tipe Student Teams-Achievement Divisions (STAD) pada materi pecahan, siswa terlihat aktif dalam pembelajaran, melakukan kegiatan diskusi, melakukan tanya jawab, membuat dan menyajikan hasil karya. Guru juga terlihat aktif dalam membimbing siswa untuk menemukan masalah, membimbing siswa mengumpulkan data yang diperlukan, membimbing siswa melakukan diskusi, mengajukan pertanyaan kepada siswa. Hal ini membuktikan bahwa penerapan model pembelajaran kooperatif tipe Student TeamsAchievement Divisions (STAD) menjadikan pembelajaran lebih aktif dilihat dari 
meningkatkan keaktifan siswa dalam pembelajaran Siklus I dan Siklus II.

Peningkatan kekatifan siswa dari siklus I ke siklus II di kelas V SDN Pranan 02 terjadi karena penerapan model pembelajaran kooperatif tipe Student Teams-Achievement Divisions (STAD). Sesuai dengan pendapat Sardiman (2006: 100) menerangkan bahwa keaktifan adalah kegiatan yang berupa fisik maupun mental yaitu berbuat dan berpikir yang menghasilkan keaktifan dalam pembelajaran yang optimal. Pembelajaran yang menyenangkan akan membuat siswa menjadi aktif. Keaktifan merupakan prinsip atau asas yang sangat penting dalam interaksi belajar mengajar. Thorndike dalam Dimyati (2010:45) berpendapat keaktifan belajar siswa dalam belajar dengan hukum "law of exercise"-nya menyatakan bahwa belajar memerlukan adanya latihan- latihan dan Mc Keachie menyatakan berkenan dengan prinsip keaktifan mengemukakan bahwa individu merupakan "manusia belajar yang aktif ingin selalu tahu. Segala pengetahuan harus diperoleh dengan pengamatan dan pengalaman sendiri. Hal tersebut akan muncul jika anak mempunyai minat dan rasa ingin tahu yang tinggi.

Untuk melihat perkembangan kemajuan setiap siklus dapat dilihat pada tabel berikut.

Tabel 4. Perbandingan Hasil Penelitian pada setiap siklus

\begin{tabular}{lcc}
\hline \multicolumn{1}{c}{ Aspek } & Siklus I & Siklus II \\
\hline $\begin{array}{l}\text { Jumlah siswa } \\
\text { aktif }\end{array}$ & 11 & 20 \\
\hline $\begin{array}{l}\text { Prosentase siswa } \\
\text { aktif (\%) }\end{array}$ & 47,83 & 86,96 \\
\hline $\begin{array}{l}\text { Skor rata-rata } \\
\text { penilaian guru }\end{array}$ & 3,57 & 3,78 \\
\hline $\begin{array}{l}\text { Rata-rata nilai } \\
\text { kuis individual }\end{array}$ & 72,04 & 83,26 \\
\hline
\end{tabular}

Dari table 4 dapat dijeaskan bahwa terdapat perkembangan dilihat dari 6 aspek. Jumlah siswa aktif dari 11 pada siklus satu dengan prosentse $47,83 \%$ menjadi 20 siswa pada siklus dua dengan prosentase $86,96 \%$. Skor rata-rata penilaian guru jga eningkat dari 3,57 pada siklus satu menjadi 3,78 pada siklus dua. Ratarata nilai kuis siswa pada siklus satu adalah 72,04 dan mengalami kenaikan pada siklus 2 menjadi 83,26.

Data perbandingan ketuntasan klasikal hasil belajar sebelum dan sesudah pelaksanaan Siklus II dapat dilihat pada Tabel 5.

Tabel 5 Data Ketuntasan Kalsikal Hasil Belajar Siswa

\begin{tabular}{clccc}
\hline No. & $\begin{array}{c}\text { Ketuntasan } \\
\text { Klasikal }\end{array}$ & $\begin{array}{c}\text { Pra } \\
\text { Siklus }\end{array}$ & $\begin{array}{c}\text { Siklus } \\
\text { I }\end{array}$ & $\begin{array}{c}\text { Siklus } \\
\text { II }\end{array}$ \\
\hline 1 & Tuntas & $30,43 \%$ & $62,22 \%$ & $91,30 \%$ \\
\hline 2 & Belum Tuntas & $69,57 \%$ & $34,78 \%$ & $8,70 \%$ \\
\hline
\end{tabular}

Tabel 5 menunjukkan bahwa sebelum tindakan persentase ketuntasan klasikal sebesar $30,43 \%$ siswa tuntas sesuai dengan KKM. Setelah mengikuti pembelajaran Siklus I meningkat menjadi $62,22 \%$ siswa telah tuntas memenuhi KKM. Persentase ketuntasan klasikal ini terus mengalami peningkatan setelah mengikuti pembelajaran pada Siklus II dimana $91,30 \%$ siswa telah mencapai indikator keberhasilan dengan KKM 70. Siswa yang tuntas $>80 \%$ maka PTK ini telah mencapai indikator keberhasilan. Untuk mempermudah melihat perbandingan ketuntasan klasikal hasil belajar siswa sebelum dengan sesudah tindakan Siklus II disajikan Gambar 2 sebagai berikut :

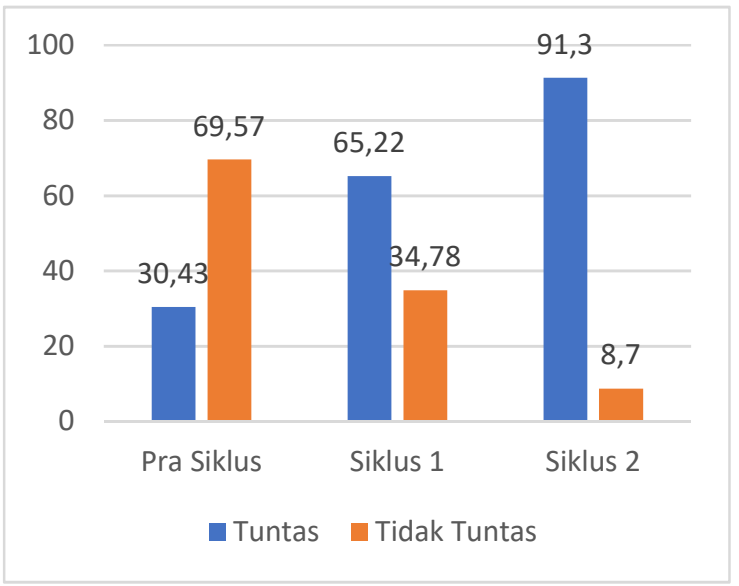

Gambar 2 Diagram Ketuntasan Belajar

Hasil analisis data tersebut menjelaskan bahwa dengan pembelajaran penerapan model pembelajaran kooperatif tipe Student TeamsAchievement Divisions (STAD) pada materi pecahan meningkatkan keaktifan dan hasil 
belajar siswa. Dalam pembelajaran ini siswa mengalami peningkatan karena siswa dapat berdiskusi dan mampu berlomba untuk mendapatkan hasil yang terbaik.

\section{SIMPULAN DAN SARAN}

Prosentase keaktifan siswa pada siklus I menunjukkan angka $63,21 \%$ yang menunjukkan katagori cukup dan pada siklus II prosentase keaktifan siswa sebesar 84,28 menunjukkan dalam kategori sangat baik. Dengan demikian terdapat peningkatan keaktifan siswa dari siklus I ke siklus II.

Hasil belajar siswa setelah penerapan model pembelajaran kooperatif tipe Student TeamsAchievement Divisions (STAD) mengalami peningkatan. Prosentase ketuntasan belajar siswa pada siklus I menunjukkan angka sebesar $65,22 \%$ (15 siswa dari jumlah 23 siswa tuntas dalam belajarnya) dan pada siklus II prosentase ketuntasan sebesar $83,26 \%$ ( 21 siswa dari jumlah 23 siswa tuntas dalam belajarnya). Dengan demikian terdapat peningkatan ketuntasan belajar siswa dari siklus I ke siklus II.

Berdasarkan kesimpulan dan datadata temuan hasil penelitian terbukti bahwa model pembelajaran kooperatif tipe Student Teams-Achievement Divisions (STAD) dapat meningkatkan kemampuan menghitung pecahan pada siswa. Maka hasil penelitian dapat diimplikasikan sebagai hasil penelitian yang dapat digunakan sebagai acuan yang tepat dalam menentukan model pembelajaran, khususnya dalam pembelajaran matematika pada konsep menghitung pecahan materi pokok penjumlahan dan pengurangan pecahan di kelas V. Penelitin ini menunjukkan pentingnya penerapan model pembelajaran yang bervariasi dan inovatif, salah satunya model pembelajaran kooperatif tipe Student Teams-Achievement Divisions (STAD) yang sudah terbukti dapat menciptakan suasana belajar yang menyenangkan sehingga dapat meningkatkan keaktifan siswa dan meningkatkan prestasi belajar siswa khususnya dalam pembelajaran matematika.

\section{DAFTAR RUJUKAN}

Ag, Moch. Masykur dan Fathani, Abdul Halim. 2008.
Intelegence. Yogyakarta: AR-Ruzz Media

Agus Suprijono. 2009. Cooperative Learning. Yogyakarta: Pustaka Pelajar

Alwi, Hasan,dkk. 2005. Kamus Besar Bahasa Indonesia (edisi ketiga). Jakarta: Balai Pustaka.

Arikunto, S. 2013. Dasar- dasar Evaluasi Pendidikan. Jakarta: PT Rineka Cipta

Depdiknas. 2006. Permendiknas nomor 22 tahun 2006 tentang Standar Isi. Jakarta: Depdiknas.

Dimyati, Mudjiono. 2010. Belajar dan Pembelajaran. Jakarta : PT. Rineka Cipta

Isjoni. 2009. Pembelajaran Kooperatif. Yogyakarta: Pustaka Pelajar

Kemmis, S dan Mc. Taggart, R (1988). The Action Research Planner, $3^{\text {rd }}$ edn. Victoria: Deakin University

Kunandar. 2013. Penilaian Autentik (Penilaian Hasil Belajar Peserta Didik berdasarkan Kurikulum 2013). Jakarta: Raja Grafindo Persada

Slavin,R. E. 2009. Cooperative Learning. Bandung: Nusa Media.

Sardiman. 2006. Interaksi dan Motivasi Belajar-Mengajar. Jakarta : PT. Raja Grafindo Persada

Sudjana, Nana. 2012. Penilaian Hasil Proses Belajar Mengajar. Bandung : PT. Remaja Rosda Karya

Sugiyanto. 2009. Model-Model Pembelajaran Inovatif. Surakarta : Panitia Sertifikasi Guru (PSG) Rayon 13. Universitas Negeri Sebelas Maret.

Tarim, Kamuran dan Akdniz, Fikri . 2007. The Effects of Cooperatif Learning on Turkish Elementary Student's Mathematic Achievment and Attitude Towards Mathematic using Tai and STAD Methods. (http://www.springerlink.com/content ly52816481542x725/18/01/2019).

Zakaria E, Ihsan Z. 2007. Promoting Cooperative Learning in Science and Mathematics Education: A Malaysian Perspective dalam Eurasia Journal of Mathematics, Science \& Technology Education, Vol 3 (1), 35-39 